\title{
Ectopic vestigial lesions of the neck and shoulders
}

\author{
DS SHAREEF,* R SALM \\ From the Department of Histopathology, Royal Postgraduate Medical School, Hammersmith Hospital, \\ London W12 OHS
}

SUMMARY A series of five vestigial lesions of the shoulder and back is reported. Their derivation is discussed and in four cases a branchial rather than a bronchial origin is favoured. The fifth case is held to represent skin involvement by thyroglossal duct elements.

Most heterotopic tissues in the head and neck are due to persistent embryonic structures, especially of the branchial and thyroglossal vestiges. ${ }^{1}$ We wish to report a series of five cases of this type from the neck and shoulders, in order to draw attention to such unusual manifestations and to discuss their disputed histogenesis.

\section{Case reports}

CASE 1

A negro female, aged 11 months, presented with a periodically discharging subcutaneous lump on her left shoulder which had been present since birth. This was situated in the left supraclavicular region overlying the supraspinatus muscle, and was attached to the deep fascia. Healing after excision was uneventful.

\section{Microscopical examination}

The subcutaneous fat contained a centrally cystic nodule, $0.5 \mathrm{~cm}$ across, which communicated with the pigmented epidermis by way of an epidermis-lined duct, its melanin pigmentation decreasing with increasing depth. Around the duct there were sweat and sebaceous glands, hair follicles and smooth muscle bundles. The central cyst, $0.3 \times 0.2 \mathrm{~cm}$, was filled with keratin squames, inflammatory exudate and scanty erythrocytes. It was preponderantly lined by ciliated pseudostratified epithelium of respiratory type with focal groups of goblet cells and a thick basement membrane (Fig. 1), but one peripheral segment was lined by keratinising nonpigmented epidermis with a prominent granular layer (Fig. 2). The subepithelial tissues were densely infiltrated with lymphocytes with an occasional

* Present address: Department of Histopathology, Mount Vernon Hospital, Northwood, Middlesex HA6 2RN.

Accepted for publication 29 April 1981 reactive centre. The fibrous cyst wall incorporated a few small sebaceous glands below the epidermis, and elsewhere there were groups of seromucinous glands, some of which were present in the adjacent fat tissue. In one level there were also a number of smooth muscle bundles.

\section{CASE 2}

A four-year-old girl presented from birth with a subcutaneous cyst on her left shoulder overlying the acromial process. There had been a slight discharge from the lesion for a week before excision. Healing was uneventful.

\section{Microscopical examination}

The lumen of the cyst was filled with pus. The cyst lining had a somewhat wavy outline and consisted mainly of ciliated pseudostratified epithelium of respiratory type with many goblet cells, demarcated by a delicate basement membrane (Fig. 3). One small area was lined by epidermis with underlying small sweat glands (Fig. 4). A narrow zone of dense chronic inflammatory infiltrate was present below both types of epithelium, followed by a thin ring of fibrous tissue with occasional smooth muscle bundles. There were no mucous glands.

\section{CASE 3}

A 22-year-old woman underwent an operation for the excision of the right thyroid lobe for presumptive colloid nodule. The subcapsular thyroid parenchyma showed posteriorly an area of fibrosis with many small cysts containing pale mucoid material.

\section{Microscopical examination}

Hyaline fibrous tissue, $2 \times 1.2 \mathrm{~cm}$, replaced the periphery of the thyroid lobe, with widespread vascular proliferations which varied in size from capillary to sinusoidal. There were numbers of 

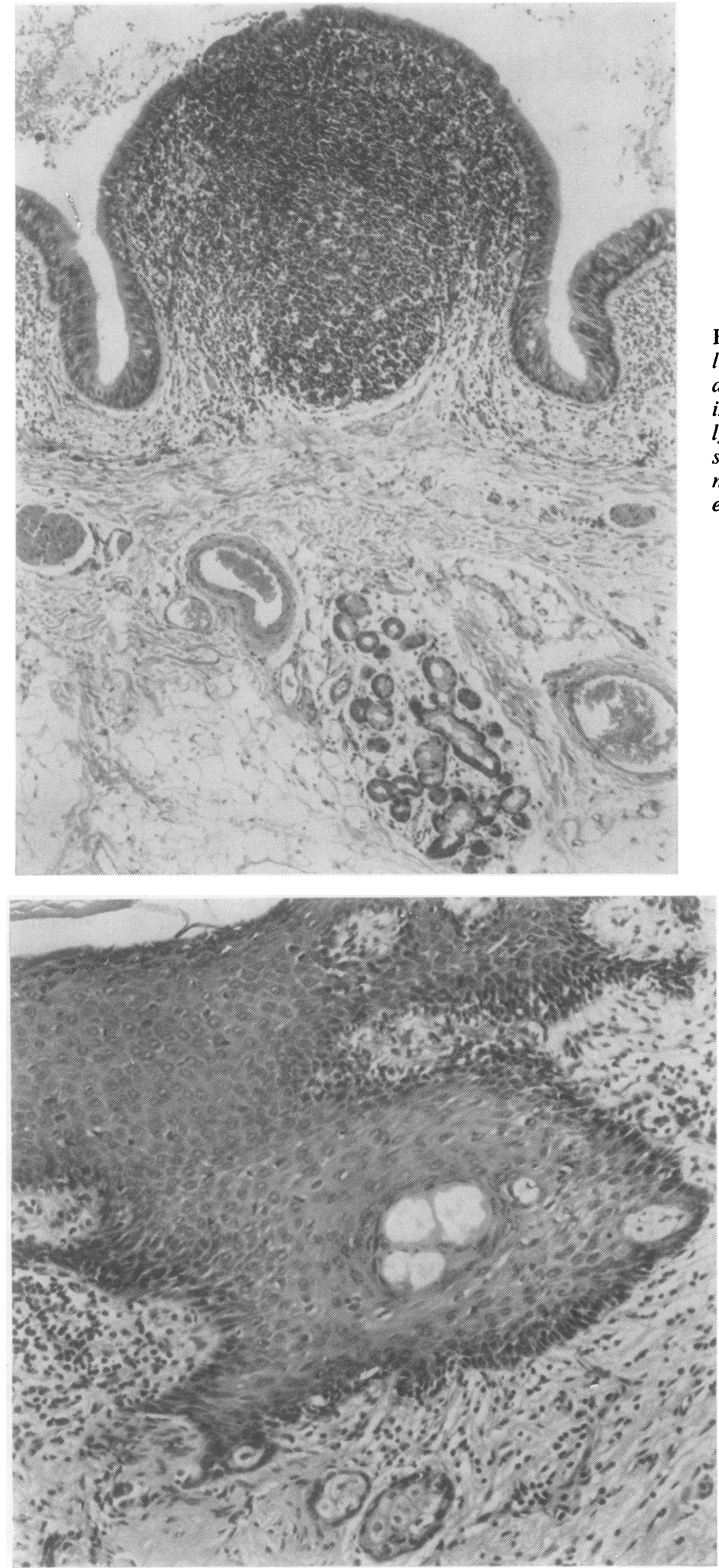

Fig. 1 Case 1. Corrugated cyst wall lined by respiratory epithelium with distinct basement membrane covered by inflammatory exudate. Underlying lymphoid tissue with reactive centre, small seromucinous gland and two small smooth muscles left and right. Haematoxylin and $\operatorname{eosin} \times 60$.

Fig. 2 Case 1. Segment of cyst wall lined by hyperkeratotic epidermis with small sebaceous glands at bottom.

Haematoxylin and eosin $\times 150$. 


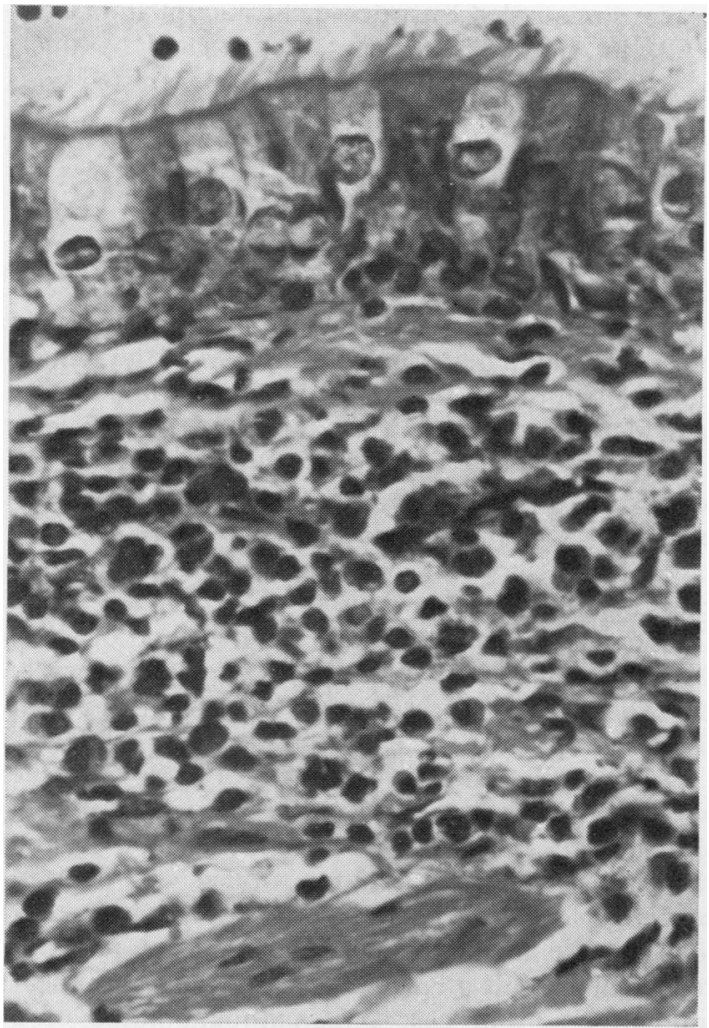

Fig. 3 Case 2. Cyst wall lined by ciliated respiratory epithelium covered by inflammatory exudate. Underneath a zone of lymphoid infiltrate with smooth muscle at bottom. Haematoxylin and eosin $\times 600$.

incorporated glandular tubules and cysts, measuring up to $0.6 \mathrm{~cm}$ across (Fig. 5). The larger cysts were lined by flattened epithelium and often contained mucin. Elsewhere the lining epithelium was of the ciliated pseudostratified respiratory type with occasional goblet cells and an inconspicuous basement membrane, sometimes bordered by a smooth muscle layer with underlying seromucinous glands (Fig. 6). A single cyst was lined by thick, nonkeratinising stratified epithelium with a patchily thickened basement membrane, and this was the only cyst to show subepithelial lymphocytic infiltration (Fig. 7). Loosely arranged smooth muscle fibres were encountered along the periphery of an occasional glandular structure, and smooth muscle fibres and groups of seromucinous glands were also distributed haphazardly in the fibrous stroma.

\section{CASE 4}

A 26-year-old woman was admitted for hyperparathyroidism. A parathyroid adenoma was excised together with an adjacent small tissue nodule, $0.9 \times 0.5 \mathrm{~cm}$.

\section{Microscopical examination}

The separate nodule consisted of fibrous tissue with many incorporated large tubular and cystic spaces of irregular outline, measuring up to $0.4 \times 0.2 \mathrm{~cm}$, some of which contained mucin. These were lined by ciliated epithelium of respiratory type (Fig. 8) with varying numbers of goblet cells. There was a patchy dense subepithelial lymphocytic infiltrate, but smooth muscle and mucous glands were absent.

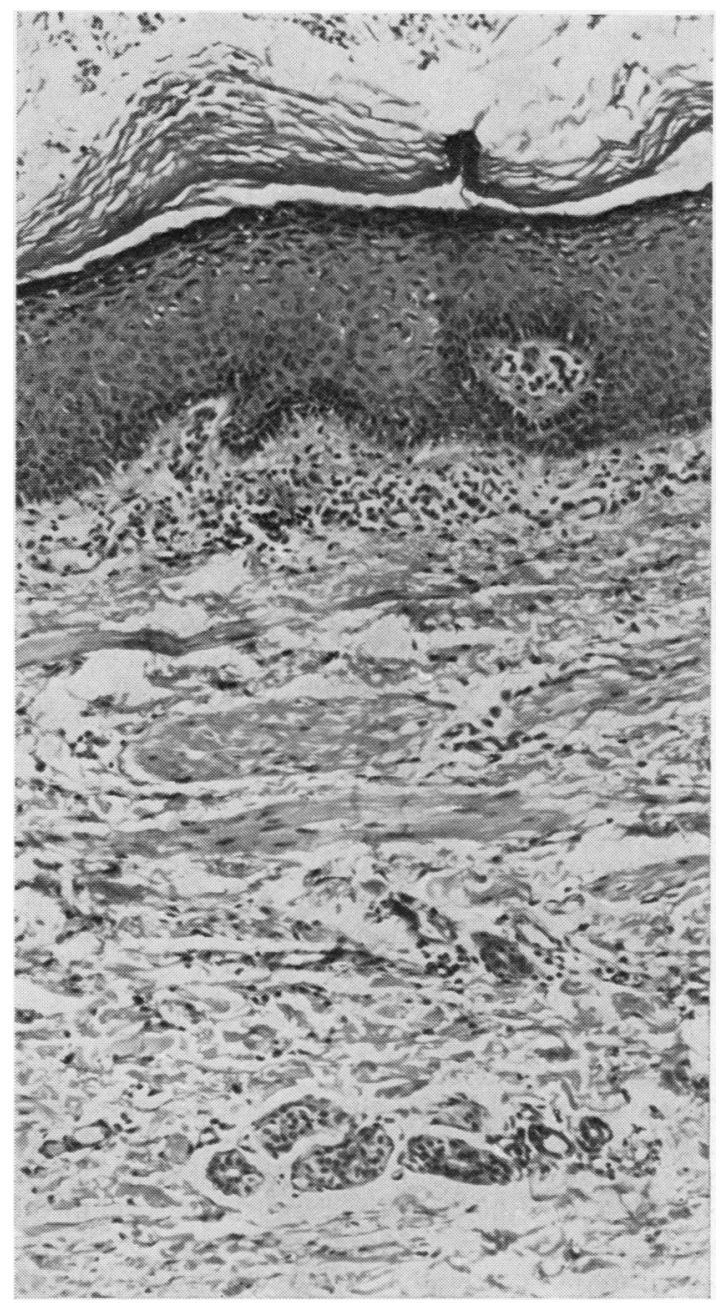

Fig. 4 Case 2. Segment of cyst wall lined by hyperkeratotic epidermis covered by inflammatory exudate with underneath a zone of smooth muscle bundles. Small sweat glands at bottom. Haematoxylin and eosin $\times 150$. 


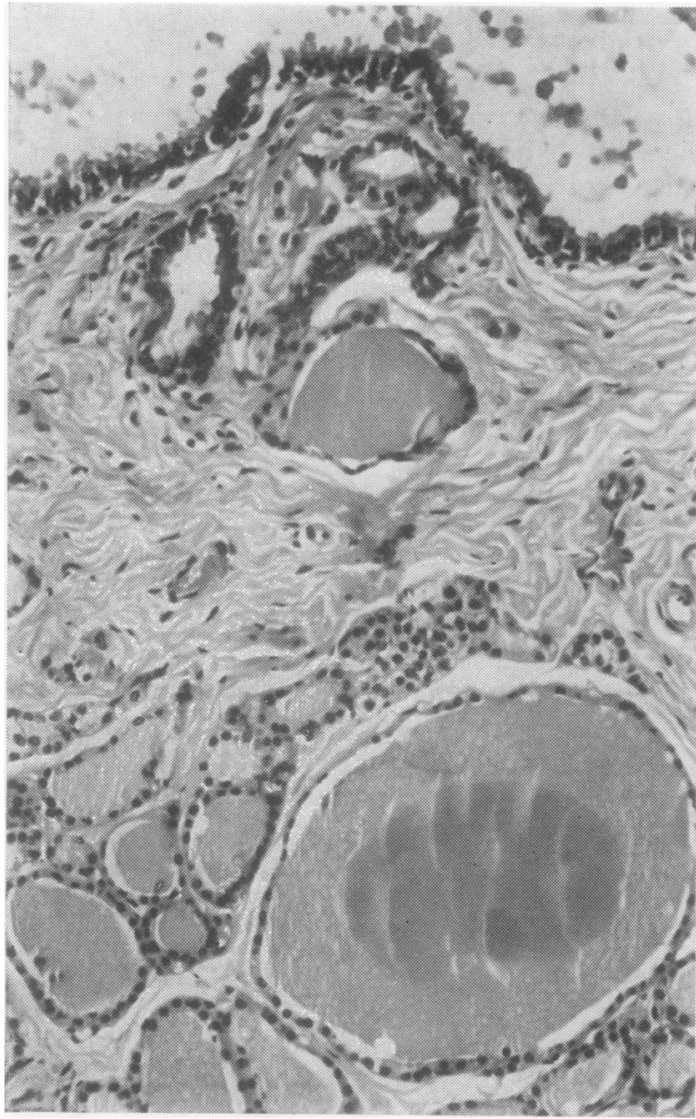

Fig. 5 Case 3. Cyst wall lined by low respiratory epithelium and adjacent thyroid tissue. Haematoxylin and eosin $\times 150$.

\section{CASE 5}

A 17-year-old woman underwent an operation for the excision of a longitudinal, granular, depressed area of skin in the midline of the neck measuring $5 \times 0.5 \mathrm{~cm}$, which had been present since birth. The patient was symptom free four years later.

\section{Microscopical examination}

Cross-sections through the excised strip of skin consisted of striated muscle, presumably platysmal, covered by skin. Along the excisional margins the epidermis was thin and the dermis contained sweat and sebaceous glands. More centrally the epidermis was acanthotic and the underlying corium lacked any skin appendages. Instead, there were numbers of short perpendicular tubules which opened on to the skin surface (Fig. 9). These were lined by ciliated pseudostratified epithelium of respiratory type with many goblet cells and a delicate hasement mem- brane, surrounded by a dense chronic inflammatory infiltrate. Branching tubules, demarcated by thick basement membranes (Fig. 10), penetrated the striated muscle to a depth of $0 \cdot 2 \mathrm{~cm}$.

\section{Discussion}

The salient features of the five cases are listed in Table 1. All our patients were females, in contrast to the findings of Fraga et $a .^{2}$ of a male preponderance $\approx$ of $5: 1$, based on material from the files of the Armed $\vec{\circ}$ Forces Institute of Pathology. As one would expect with developmental lesions, our three superficially situated cases were detected at birth. The two lesions located in the deeper tissues were only demonstrated on microscopical examination of the excised tissues.

The small shoulder cyst of case 1 had had a discharging sinus, whereas the discharge of the larger shoulder cyst of case 2 had been slight and of short duration, thus suggesting that cyst size is largely dependent on the presence or absence of a patent fistula.

Microcystic lesions embedded in fibrous tissue were noted in cases 3 and 4, the lesion of case 3 being situated within the substance of the thyroid lobe, and that of case 4 adjacent to it. One of the cysts reported by Fraga et al. ${ }^{2}$ was also present close to a thyroig lobe, but we have been unable to trace any previou report of an intrathyroidal localisation. The linea midline lesion of case 5 is pathognomonic of derivation from the thyroglossal duct. The remaining four lesions were interpreted as being of branchial rather than of bronchial origin for reasons discussed below.

The one microscopical feature common to all five cases was the presence of ciliated respiratory epithelium which lined the cysts preponderantly or exclusively. Smaller areas of epidermis or stratified epithelium were present in cases 1,2 , and 3 , the epidermis in case 1 being associated with sebaceous glands, and in case 2 with sweat glands. A patchily thickened basement membrane was noted in cases 1 , 3, and 5, a feature also noted by Fraga et al. ${ }^{2}$ and Drut et $a l^{3}$ The chronic subepithelial inflammatory infiltrate was dense in cases 1 and 2, which had had discharging sinuses, but in the remaining cases such infiltrate was either focal or minimal. Smooth muscles were present in cases 1,2 , and 3 , and seromucinous glands in cases 1 and 3. Most of these findings are in agreement with those of previous reports; the similarities and differences are summarised in Tables 1 and 2 .

As to pathogenesis, there is general consensus that lesions of this type are not teratomatous, because of the presence only of tissue elements compatible with a derivation from the primitive foregut. 
Table 1 Summary of five cases of ectopic vestigial lesions of neck and shoulders

\begin{tabular}{|c|c|c|c|c|c|c|c|c|c|c|}
\hline $\begin{array}{l}\text { Case } \\
\text { No }\end{array}$ & Sex & $\begin{array}{l}\text { Age at } \\
\text { presentation } \\
(y r)\end{array}$ & Site & $\begin{array}{l}\text { Size } \\
(\mathrm{cm})\end{array}$ & $\begin{array}{l}\text { Macroscopical } \\
\text { appearance }\end{array}$ & $\begin{array}{l}\text { Respiratory } \\
\text { epithelium }\end{array}$ & $\begin{array}{l}\text { Goblet } \\
\text { cells }\end{array}$ & $\begin{array}{l}\text { Epidermis } \\
\text { or } \\
\text { stratified } \\
\text { epithelium }\end{array}$ & $\begin{array}{l}\text { Sero- } \\
\text { mucinous } \\
\text { glands }\end{array}$ & $\begin{array}{l}\text { Smooth } \\
\text { muscle }\end{array}$ \\
\hline $\begin{array}{l}1 \\
2 \\
3 \\
4 \\
5\end{array}$ & $\begin{array}{l}\mathbf{F} \\
\mathbf{F} \\
\mathbf{F} \\
\mathbf{F} \\
\mathbf{F}\end{array}$ & $\begin{array}{l}11 / 12 \\
4 \\
22 \\
26 \\
17\end{array}$ & $\begin{array}{l}\text { Shoulder } \\
\text { Shoulder } \\
\text { Intrathyroidal } \\
\text { Juxtathyroidal } \\
\text { Midline of neck }\end{array}$ & $\begin{array}{l}0.4 \\
4 \\
2.5 \times 1.2 \\
0.8 \times 0.5 \\
5 \times 0.3\end{array}$ & $\begin{array}{l}\text { Single cyst } \\
\text { Single cyst } \\
\text { Microcystic } \\
\text { Microcystic } \\
\text { Linear scar }\end{array}$ & $\begin{array}{l}+ \\
+ \\
+ \\
+ \\
+\end{array}$ & $\begin{array}{l}+ \\
+ \\
+ \\
+ \\
+\end{array}$ & $\begin{array}{l}+ \\
+ \\
+ \\
-\end{array}$ & $\begin{array}{l}+ \\
\pm \\
+ \\
-\end{array}$ & $\begin{array}{l}+ \\
+ \\
+ \\
-\end{array}$ \\
\hline
\end{tabular}

Table 2 Summary of previously reported subcutaneous vestigial cysts of neck and thorax

\begin{tabular}{|c|c|c|c|c|c|c|c|c|}
\hline References & $\begin{array}{l}\text { No of } \\
\text { cases }\end{array}$ & Site & $\begin{array}{l}\text { Respiratory } \\
\text { epithelium }\end{array}$ & $\begin{array}{l}\text { Goblet } \\
\text { cells }\end{array}$ & $\begin{array}{l}\text { Stratified } \\
\text { epithelium }\end{array}$ & $\begin{array}{l}\text { Sero- } \\
\text { mucinous } \\
\text { glands }\end{array}$ & $\begin{array}{l}\text { Smooth } \\
\text { muscle }\end{array}$ & Cartilage \\
\hline $\begin{array}{l}{ }^{12} \text { Seybold and Clagett } \\
\quad 1948 \\
\\
{ }^{2} \text { Fraga et al. } 1971\end{array}$ & $\begin{array}{r}1 \\
30\end{array}$ & $\begin{array}{l}\text { Presternal } \\
26 \text { in or near suprasternal } \\
\text { notch } \\
3 \text { over scapula } \\
1 \text { on shoulder }\end{array}$ & + & + & - & $16 / 30$ & $24 / 30$ & $2 / 30$ \\
\hline $\begin{array}{l}{ }^{8} \text { Constant et al. } 1973 \\
{ }^{3} \text { Drut } \text { et al. } 1974\end{array}$ & $\begin{array}{l}1 \\
4\end{array}$ & $\begin{array}{l}\text { Suprasternal notch } \\
\text { Suprasternal notch }\end{array}$ & $\begin{array}{l}+ \\
4\end{array}$ & + & $\stackrel{+}{-}$ & ${ }_{4}^{+}$ & ${ }_{4}^{+}$ & $\overline{-}$ \\
\hline
\end{tabular}

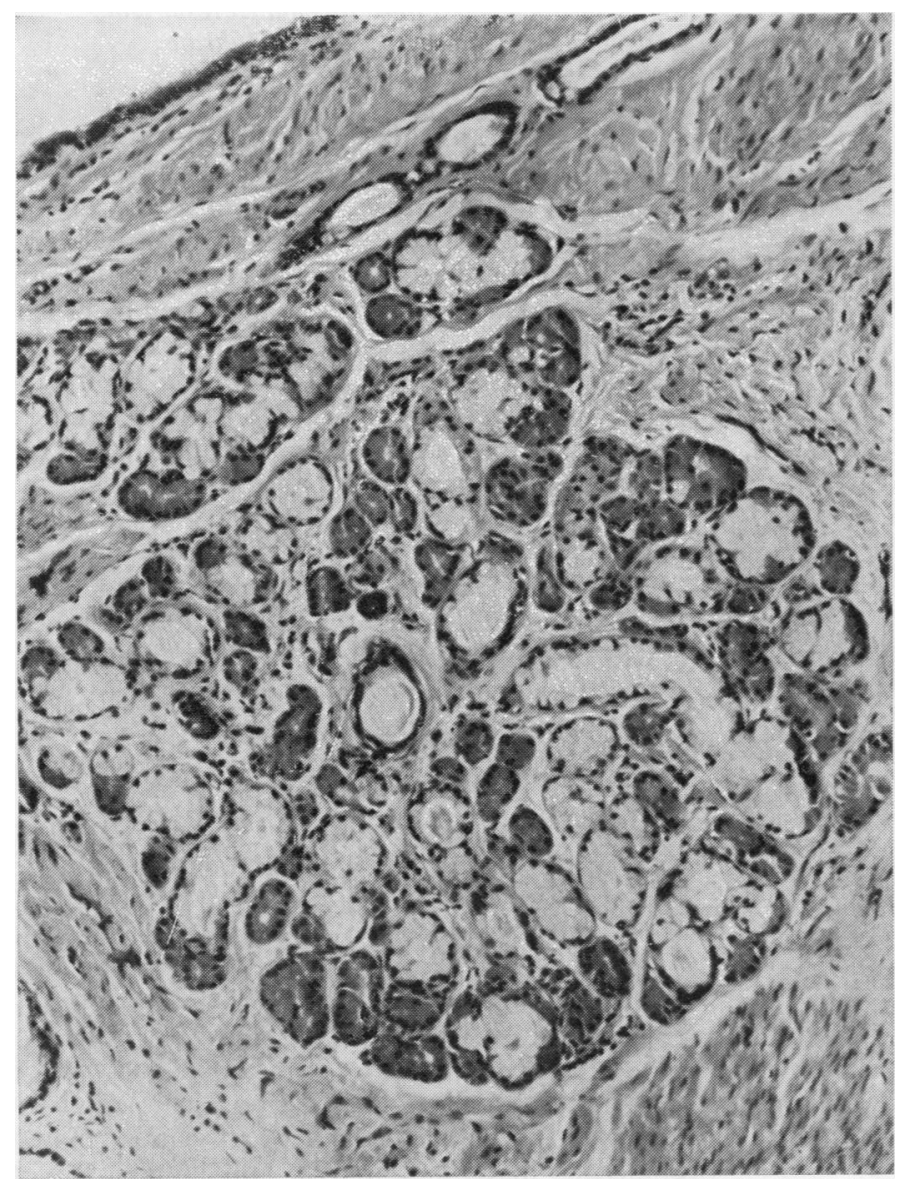

Fig. 6 Case 3. Cyst wall lined by respiratory epithelium. Underneath a zone of smooth muscles and large seromucinous gland. Haematoxylin and eosin $\times 150$. 
The two modes of histogenesis considered most likely are origins from the branchial pouches or from the respiratory buds. The chief protagonists that such cysts represent ectopic bronchial cysts have been Fraga et al. ${ }^{2}$ These authors put forward the view that cells from the respiratory buds are pinched off and sequestrated during early fetal development, though they did admit that the location in the shoulder and scapular areas in four of their patients was difficult to explain on this basis. Cogent arguments, however, can be advanced against the postulated bronchial derivation of such cysts.

Firstly, although two of their cases showed the presence of sinuses leading to behind the manubrium, they were unable to demonstrate a connection with the respiratory system. On the other hand, some branchial cysts possess lower pedicles, and lower

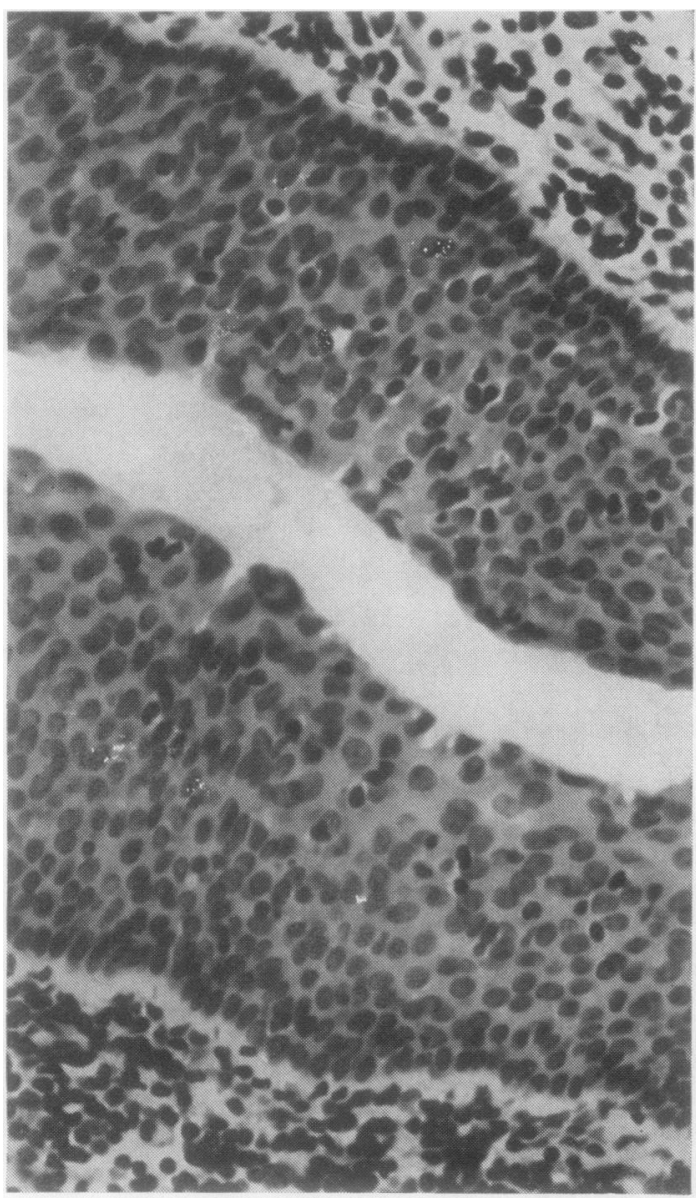

Fig. 7 Case 3. Cyst lined by stratified epithelium with distinct basement membrane and adjacent lymphoid infiltrate. Haematoxylin and eosin $\times 400$.

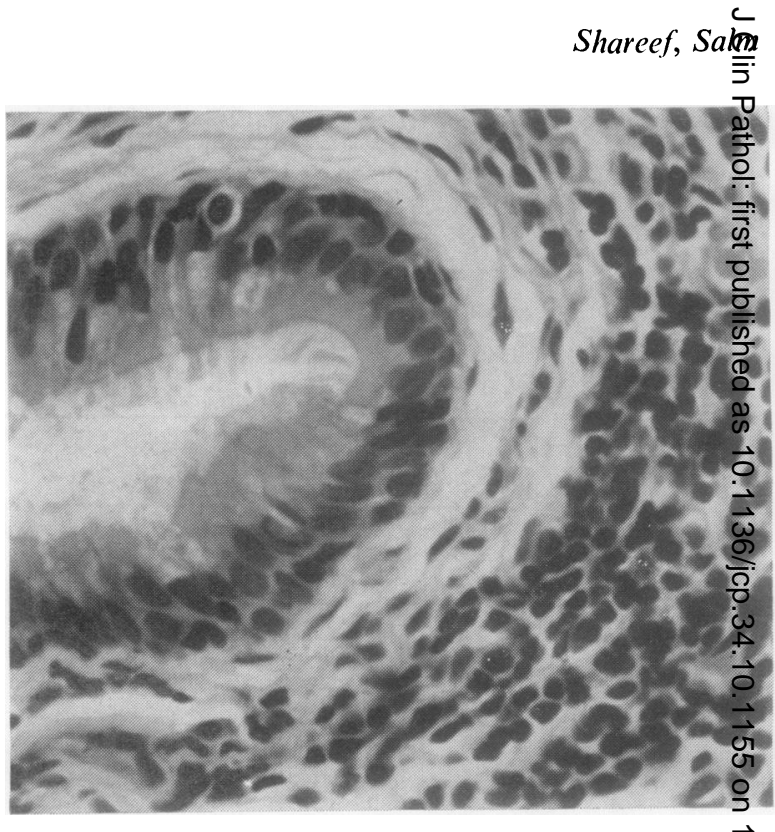

Fig. 8 Case 4. Cyst lined by ciliated respiratory epithelium with adjacent lymphoid infiltrate.

Haematoxylin and eosin $\times 600$.

external as well as upper internal sinuses have been $\overrightarrow{0}$ found in about one-third of all branchial cysts Secondly, intrathoracic bronchial cysts are not. infrequently associated with other congenital abnot malities. ${ }^{5}$ In contrast, no other congenital lesions, including skeletal defects, have ever been recorded in association with the cysts under discussion.

Fraga et al. ${ }^{2}$ rejected a branchial origin for several $\stackrel{2}{\rightarrow}$ reasons: the presence of smooth muscle and sero- $\frac{0}{3}$ mucinous glands; the paucity of lymphoid tissue; the occasional presence of cartilage; and their most common anatomical sites in or near the suprasternal notch.

As to the presence of seromucinous glands, these $\frac{\dot{0}}{7}$ have occasionally been seen in the walls of branchial cysts. ${ }^{4}$ But whereas bronchial cysts are lined by $ᄋ$ respiratory epithelium and possess smooth muscle $₹$ coats, branchial cysts are predominantly lined by 응 stratified epithelium and lack smooth muscle in their walls.

This morphological difference is usually attributed to branchial clefts being of ectoendodermal deri- $\Omega$ vation. However, if sequestration of cells should $\tilde{O}$ occur both early in fetal life as well as from the $\underset{\omega}{N}$ deeper-that is, from the endodermal parts of the branchial cleft membrane, then differentiation to respiratory epithelium is as likely to occur as in $\frac{\bar{D}}{\mathrm{D}}$ sequestrations from the respiratory bud. Mucous $\stackrel{\mathcal{P}}{\rightarrow}$ glands are also likely to develop, analogous to the 7 formation of sebaceous and sweat glands below the $\bar{O}$ epidermis in cases 1 and 2 , and induction of the $\stackrel{\mathbb{Q}}{Q}$ 


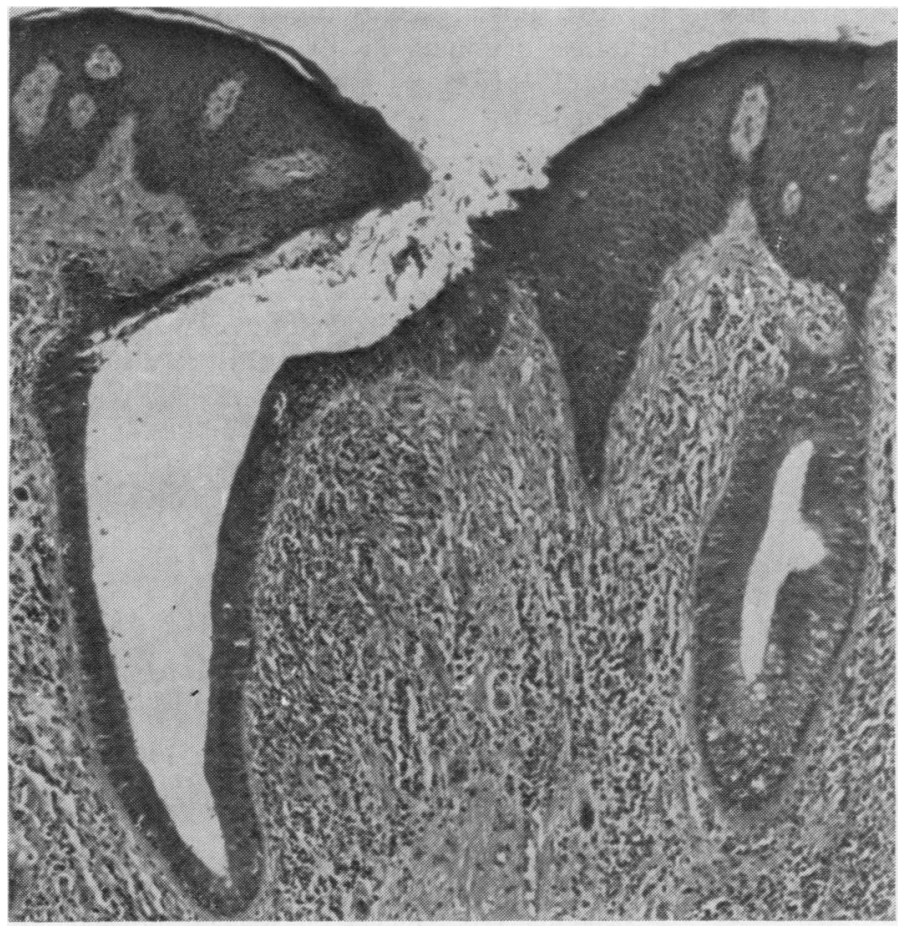

Fig. 9 Case 5. Tubular glands lined by respiratory epithelium opening on to skin surface surrounded by lymphoid infiltrate. Haematoxylin and eosin $\times 60$.

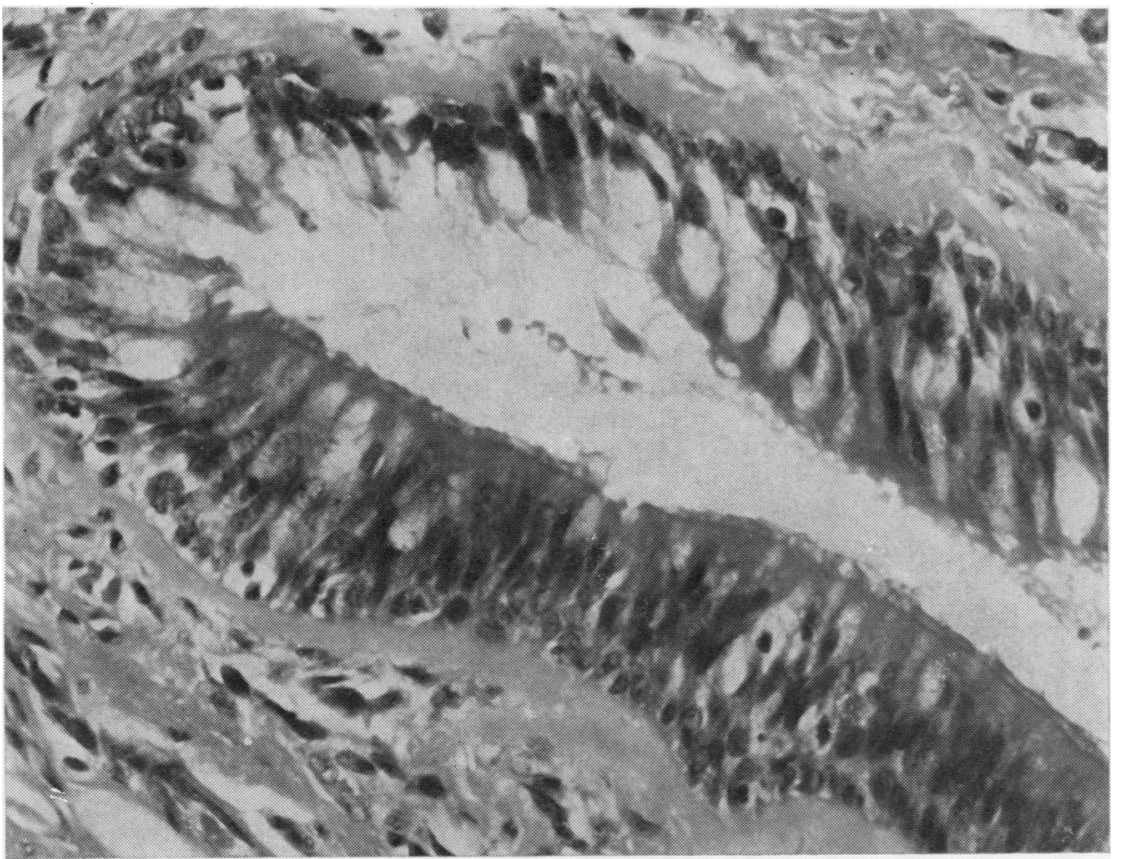

Fig. 10 Case 5.

Deeper tubular gland lined by ciliated respiratory

epithelium with many goblet cells and thick basement membrane. Haematoxylin and $\operatorname{eosin} \times 400$. 
surrounding primitive mesenchyme to form smooth muscle and, more rarely, of cartilage, can be readily envisaged.

Cysts with discharging sinuses become infected, and their florid lymphoid tissue should be regarded as a secondary reaction, as already pointed out by Nicholson. ${ }^{6}$ Thus, the paucity of lymphoid tissue in some of the cysts under consideration probably reflects the fact that they were closed cysts, and does not exclude a branchial derivation.

Contrary to the contention of Fraga et al., ${ }^{2}$ the occasional presence of cartilage is not proof of a bronchial origin, for islands of cartilage have been demonstrated in the walls of branchial cysts ${ }^{4}$ 7 hence the term "cervical auricles" of the earlier literature. ${ }^{4}$

Finally, the commonest location of these cysts held by some authors to be of bronchial origin, namely at or near the suprasternal notch, is indeed also the common site of the skin orifices of external branchial fistulas, as stressed in an editorial footnote to the communication of Constant et al. ${ }^{8}$

We would also re-emphasise the difficulty of explaining the presence of such cysts in the scapular and shoulder regions, of which our cases 1 and 2 are further examples, if one assumes them to be of bronchial origin. However, if one regards them as of branchial origin, no such difficulty is encountered. For whereas late in fetal life the branchial clefts are remote from such ectopic sites as the upper chest wall, upper back and shoulder regions, during the early stages of embryonic development, the branchial pouches are in close proximity to those areas destined to form these parts of the body, and sequestrated cells from the branchial clefts may be carried along with, for example, the developing limb buds. With this postulated development no other associated malformations need be expected. Hence we would conclude that, although neither a branchial nor a bronchial origin of such cysts can be proven conclusively, a branchial origin appears to be more likely.

The lesion of case 5, unlike the other four, we regard as of thyroglossal duct origin. Persistence of the thyroglossal stalk is known to give rise to medial fistulous openings in the neck, ${ }^{9-11}$ but we are unaware of any previous report with skin involvement.

We wish to record our gratitude to Dr JW Magner, Cork, and to Dr I Zayid, Halifax, Nova Scotia for generously furnishing us with material and clinical information of case 2 and case 5 respectively. We are greatly indebted to Professor JG Azzopardi for his interest and help, and to Professor NA Wright for reading the manuscript. The skilled photomicrography was the work of Mr W Hinkes.

\section{References}

${ }^{1}$ Willis RA. Some unusual heterotopias. $\mathrm{Br}$ Med J 1968 ;iii: 267-72.

2 Fraga S, Helwig EB, Rosen SH. Bronchogenic cysts in the skin and subcutaneous tissue. Am J Clin Pathol 1971 ;56: 230-8.

${ }^{3}$ Drut R, Castelletto RH, Duclouc KH. Quiste broncogénico de la piel. Med Cutan Iber Lat Am 1974;2:81-5.

4 Willis RA. The borderland of embryology and pathology. 2nd ed. London: Butterworths, 1962:283-9.

${ }^{5}$ Filler D, Feustel H, Hermstein N, Maintz J. Die bronchogene Zyste. Med Klin 1978;73:34-6.

- Nicholson GW. Studies on tumour formation. Guy's Hospital Reports 1922;72:193-218.

7 Bailey H. The clinical aspects of branchial fistulae. $\mathrm{Br} J$ Surg 1933;21:173-82.

8 Constant E, Davis DG, Edminster R. Bronchogenic cyst of ${ }^{*}$ the suprasternal area. Plast Reconstr Surg 1973;52:88-90.

- Schweitzer R. Demonstration eines Röntgenbildes mit offenem Ductus thyroglossus. Schweiz Med Wochenschr $1929 ; 10: 250$.

${ }^{10}$ Sgalitzer KE. Contribution to the study of the morphogenesis of the thyroid gland. J Anat 1941;75:389-405.

11 Arey LB. Developmental Anatomy. A textbook and laboratory manual of embryology. 7th ed. Philadelphia and London: Saunders, 1965:242-3.

12 Seybold WD, Clagett OT. Presternal cyst. Report of a case. Journal of Thoracic Surgery 1945;14:217-20.

Requests for reprints to: Dr R Salm, Histopathology Department, Royal Postgraduate Medical School, Hammersmith Hospital, DuCane Road, London W12 OHS, England. 